\title{
Meningkatkan Kepercayaan Diri Dalam Berkomunikasi Lisan Melalui Layanan Bimbingan Kelompok Di Kelas XII ATP 1 SMK Negeri 1 Pasir Penyu Tahun 2019
}

\author{
Fitriani \\ SMK Negeri 1 Pasir Penyu \\ Email: fitrianispd@sisfoakreditasiprodi.my.id
}

\begin{abstract}
Abstrak
Adapun tujuan penelitian ini adalah untuk meningkatkan kepercayaan diri dalam berkomunikasi lisan siswa Kelas XII ATP 1 SMK Negeri 1 Pasir Penyu melalui layanan bimbingan kelompok. Bagi siswa; Memperbaiki dan meningkatkan rasa percaya diri dalam berkomunikasi lisan siswa Kelas XII ATP 1, meningkatkan keaktifan siswa dalam berkomunikasi dalam proses pembelajaran sehingga hasil belajarnya juga akan meningkat. Bagi guru; Meningkatkan pengetahuan, keterampilan dan sikap dalam memberikan layanan konseling, dapat memperbaiki teknik melakukan konseling, Karena dengan adanya metode yang digunakan menarik bagi siswa. Bagi sekolah; Meningkatkan kualitas diri siswa, kualitas pendidikan, meningkatkan kualitas guru dan hasil belajar siswa. Penelitian ini merupakan Penelitian Tindakan Kelas (PTK) terdiri dari dua siklus, pada siklus pertama dilakukan tindakan bimbingan koseling kepada siswa dengan metode ceramah, Selanjutnya pada siklus kedua dilakukan tindakan bimbingan kelompok menggunakan metode permaianan game role play. Berdasarkan hasil refleksi dari siklus pertama. Ada empat tahapan yang dilakukan dalam penelitian tindakan yaitu persiapan, pelaksanaan, observasi, dan refleksi. Hasil siswa setelah dilakukan bimbingan kelompok dalam koseling yang diterapkan dalam penelitian ini sehingga hipotesis tindakan yang diajukan dapat diterima. Dengan kata lain bahwa dengan bimbingan kelompok menggunakan gamre role play pada bimbingan konseling dapat meningkatkan kepercayaan diri dalam berkomunikasi lisan siswa di Kelas XII ATP 1 SMK Negeri 1 Pasir Penyu. Sebaiknya guru BK menerapkan metode permainan berupa game dalam memberikan layanan konseling disebabkan model ini dapat mengatasi kesulitan-kesulitan dalam memberikan bimbingan konseling kepada siswa yang kurang rasa percaya diri, sulit berkomunikasi secara lisan, dan kepada siswa yang pasif, dalam proses pembelajaran. Kepada peneliti selanjutnya hendaklah mencoba menggunakan model bimbingan ini pada kegiatan bimbingan konseling lainnya.
\end{abstract}

Kata Kunci: Kepercayaan Diri dalam Komunikasi Lisan, Bimbingan kelompok

\begin{abstract}
The purpose of this study was to increase self-confidence in oral communication for students of Class XII ATP 1 SMK Negeri 1 Pasir Penyu through group guidance services. For student; Improve and increase selfconfidence in verbal communication for students of Class XII ATP 1, increasing student activity in communicating in the learning process so that their learning outcomes will also increase. For teachers; Increasing knowledge, skills and attitudes in providing counseling services can improve counseling techniques, because the methods used are attractive to students. For schools; Improve the quality of students themselves, the quality of education, improve the quality of teachers and student learning outcomes.This research is a Classroom Action Research (CAR) consisting of two cycles, in the first cycle counseling action to students with the lecture method is carried out, then in the second cycle group guidance actions are carried out using the role play game method. Based on the results of the reflection from the first cycle. There are four stages in action research, namely preparation, implementation, observation, and reflection. Student results after group guidance in counseling were applied in this study so that the proposed action hypothesis could be accepted. In other words, group guidance using gamre role play in counseling can increase self-
\end{abstract}


confidence in verbal communication of students in Class XII ATP 1 SMK Negeri 1 Pasir Penyu. It is better if counseling teachers apply game methods in the form of games in providing counseling services because this model can overcome difficulties in providing counseling guidance to students who lack self-confidence, have difficulty communicating verbally, and to students who are passive, in the learning process. The next researcher should try to use this guidance model in other counseling guidance activities.

Keywords: Confidence in Oral Communication, Group guidance

\section{PENDAHULUAN}

Pada hakikatnya siswa adalah manusia yang merupakan makhluk sosial dan senantiasa ingin berinteraksi dengan manusia lainnya. Ketika seorang masuk dalam lingkungan pendidikan sebagai siswa, maka dia dituntut untuk selalu dapat bersosialisasi, bergaul dan berkomunikasi dalam lingkungannya dengan baik dan lancar. Manusia dalam kehidupan sehari-hari melakukan komunikasi tanpa menggunakan teori dan metode tertentu, diantaranya bahkan mampu berkomunikasi dengan sangat baik, sehingga semua pesan yang ingin disampaikannya mudah untuk difahami. Kemampuan berkomunikasi yang baik dapat menjadi bekal untuk karir pribadi dan sosial. Namun tidak semua orang dapat berkomunikasi dengan baik secara alamiah. Oleh sebab itu pendidikan dan pelatihan komunikasi diperlukan untuk meningkatkan kemampuan seseorang untuk dapat berkomunikasi dengan baik.Untuk dapat berkomunikasi dengan baik dapat diperoleh apabila seseorang tersebut memiliki rasa percaya diri, sehingga dapat meningkatkan perkembangan dirinya baik melalui dunia pendidikan, oleh dirinya sendiri maupun melalui lingkungannya.

Rasa kurang percaya diri bisa juga disebabkan oleh perasaan cemas dan tidak tenang serta perasaan-perasaan lain yang mengikutinya seperti malas, kurang sabar, sulit, susah atau rendah diri. Pentingnya memiliki rasa Kepercayaan Diri dalam pembelajaran agar siswa dapat mengaktualisasikan dirinya. Aktualisasi diri adalah kemampuan seseorang untuk menemukan dan mengembangkan potensi yang dimiliki. Kepercayaan diri merupakan aspek yang sangat penting bagi sesorang untuk dapat mengembangkan potensi dirinya.Jika seseorang memiliki bekal kepercayaan diri yang baik, maka individu tersabut akan dapat mengembangkan potensinya dengan baik. Namun jika seseorang memiliki kepercayaan diri rendah, maka individu tersebut cenderung menutup diri, mudah frustasi ketika menghadapi kesulitan, canggung dalam menghadapi orang, dan sulit menerima realita dirinya.

Dengan kepercayaan diri saat maju didepan kelas, dapat meningkatkan keberanian siswa dalam menjawab pertanyaan. Selain itu dapat meningkatkan komunikasi dengan baik, memiliki ketegasan, mempuyai penampilan diri yang baik, dan mampu mengendalikan perasaan. Memiliki kepercayaan diri yang tinggi dalam diri siswa dapat membantu mencapai prestasi dan hasil belajar yang lebih baik lagi. Anak yang ragu terhadap kemampuan diri sendiri /tidak percaya diri saat pembelajaran biasanya kurang dapat berbicara atau menyampaikan pesan kepada orang lain. Dengan begitu akan terjadi proses perubahan dalam diri siswa bukan hanya pada hasil belajar tetapi juga pada perilaku dan sikap siswa, yaitu keberanian, keaktifan, dan aktualisasi diri siswa saat proses belajar mengajar. Pada kenyataan di lapangan, kondisi kepercayaan diri siswa berbeda-beda, sementara disisi lain siswa butuh komunikasi secara verbal. Siswa yang rendah rasa kepercayaan pada dirinya akan mengalami keslitan dalam berkomunikasi, untuk mengungkapkan gagasannya kepada orang lain.

Bahkan cederung menghindari untuk berkomunikasi. Menurut pengamatan peneliti siswa kelas XII ATP 1 SMK Negeri 1 Pasir Penyu memiliki Kerpercayaan diri rendah sehingga mengalami masalah dalam berkomunikasi secara lisan, yang pada akhirnya akan mengalami masalah dalam pembelajaran. Hal ini dapat dilihat dari adanya gejala-gejala yang tampak di kleas XII ATP 1 SMKN 1 Pasir Penyu diantaranya: sebagian besar siswa ragu-ragu saat berbicara di depan kelas, Diam saat ditanya guru, malu berbicara di depan kelas, Tidak berani mengeluarkan pendapat, takut melakukan sesuatu, dan Cederung Pasif saat mengikuti diskusi kelompok dalam kegiatan pembelajaran. Untuk mengatasi masalah kelas seperti yang di ungkapkan di atas, maka peneliti menggunakan layanan bimbingan kelompok. Bimbingan kelompok adalah suatu kegiatan yang dilakukan oleh sekelompok orang dengan memanfaatkan dinamika kelompok". Artinya, semua peserta dalam kegiatan kelompok saling berinteraksi, bebas mengeluarkan pendapat, menanggapi, memberi saran, dan lain sebagainya; apa yang dibicarakan itu semuanya bermanfaat untuk diri peserta yang bersangkutan sendiri dan untuk peserta lainnya (Prayitno, 1995: 178).

Dengan menggunakan layanan bimbingan kelompok menolong individu untuk dapat memahami bahwa orang-orang lain ternyata mempunyai kebutuhan-kebutuhan dan masalahmasalah yang sama berhubungan dengan aspek kepercayaan diri siswa dalam proses pembelajaran. Melalui bimbingan kelompok ini dimungkinkan akan dapat membantu masalah siswa berkaitan 
dengan kepercayaan dirinya yang kurang dalam pembelajaran Bahasa Indonesia. Karena di dalam bimbingan kelompok memfasilitasi siswa untuk bertukar pendapat, lebih mudah untuk menangkap persoalan yang dihadapinya dan cara mengatasinya.

\section{a. Hakikat Kepercayaan Diri}

Kepercayaan diri merupakan salah satu aspek kepribadian yang berfungsi untuk mendorong individu dalam meraih kesuksesan yang terbentuk melalui proses belajar individu dalam interaksinya dengan lingkungan. Dalam interaksinya, individu mendapat umpan balik yang dapat berupa hadiah dan hukuman. Kepercayaan diri di definisikan sebagai suatu keyakinan individu untuk mampu berprilaku sesuai dengan yang diharapkan. Individu yang mempunyai rasa kepercayaan diri adalah individu yang mampu bekerja secara efektif, dapat melaksanakan tugas dengan baik dan bertanggung jawab. Kepercayaan diri sering di identikkan dengan kemandirian meski demikian individu yang kepercayaan dirinya tinggi pada umumnya lebih mudah untuk terlibat secara pribadi dengan individu lain yang akan lebih berhasil dalam menjalin hubungan secara interpersonal.

c. Layanan Bimbingan Kelompok

Pengertian layanan bimbingan kelompok dalam penelitian ini adalah salah satu layanan bimbingan dan konseling yang diberikan dalam bentuk kelompok yang terdiri dari 8-15 siswa dengan memanfaatkan dinamika kelompok untuk membahas topik-topik yang aktual. Menurut Gazda (1999: 309-310) "bimbingan kelompok di sekolah merupakan kegiatan informasi kepada sekelompok siswa untuk membantu mereka menyusun rencana dan keputusan yang tepat". Bimbingan kelompok juga diselenggarakan untuk memberikan informasi yang bersifat personal, vokasional, dan sosial. Menurut Romlah (2001:3) "bimbingan kelompok merupakan salah satu teknik bimbingan yang berusaha membantu individu agar dapat mencapai perkembangannya secara optimal sesuai dengan kemampuan, bakat, minat, serta nilai - nilai yang dianutnya dan dilaksanakan dalam situasi kelompok".

Bimbingan kelompok dapat ditujukan untuk mencegah timbulnya masalah pada siswa dan mengembangkan potensi siswa. Menurut Sukardi (2002: 48) "Layanan bimbingan kelompok dimaksudkan untuk memungkinkan siswa secara bersama-sama memperoleh berbagai bahan dari nara sumber yang bermanfaat untuk kehidupan sehari-hari baik sebagai individu maupun sebagai bimbingan

kelompok diatas, maka dapat disimpulkan bahwa bimbingan kelompok adalah salah satu layanan bimbingan konseling yang dilakukan secara kelompok dengan membentuk dinamika kelompok untuk mencapai tujuan bersama. Bimbingan

\section{b. Hakekat Komunikasi Lisan}

Secara umum komunikasi memiliki peranan untuk menentukan gerak kehidupan karena hampir semua aktifitas baik secara individu, kelompok, sosial, budaya, politik, ekonomi, agama, dan hubungan antar bangsa dilakukan dengan cara berkomunikasi. Pada kenyataannya setiap manusia telah terbiasa melakukan komunikasi untuk memenuhi beragam keperluan dan kepentingan. Manusia dalam kehidupan sehari-hari melakukan komunikasi tanpa menggunakan teori dan metode tertentu, diantaranya bahkan mampu berkomunikasi dengan sangat baik, sehingga semua pesan yang ingin disampaikannya mudah untuk difahami.

Kemampuan berkomunikasi yang baik dapat menjadi bekal dalam karir pribadi dan hidup bersosial. Namun tidak semua orang dapat berkomunikasi dengan baik secara alamiah. Oleh sebab itu pendidikan dan pelatihan komunikasi diperlukan untuk meningkatkan kemampuan seseorang untuk dapat berkomunikasi dengan baik. pelajar, anggota keluarga dan masyarakat".Kegiatan bimbingan kelompok akan terlihat hidup jika di dalammya dapat terbentuk dinamika kelompok.

Dinamika kelompok merupakan media efektif bagi anggota kelompok dalam mengembangkan aspek positif ketika mengadakan komunikasi antar pribadi dengan orang lain. Dalam proses bimbingan kelompok untuk meningkatkan cara dan mutu berinteraksi diperlukan adanya dinamika kelompok yang dapat memperlancar kegiatan dalam suasana dalam kelompok. Menurut Floyd D. Ruch ( dalam Gerungan, 2002: 110): Dinamika kelompok adalah analisis dari hubungan -hubungan kelompok sosial yang berdasarkan prinsip, bahwa tingkah laku dalam kelompok itu adalah hasil dari interaksi yang dinamis antara individu-individu dalam situasi sosial.

Dalam Layanan Bimbingan Kelompok, siswa diajak bersama-sama mengemukakan pendapat tentang topik-topik yang dibicarakan dan mengembangkan bersama permasalahan yang dibicarakan pada kelompok. Sehingga terjadi komunikasi antara individu di dalam kelompoknya kemudian siswa dapat mengembangkan sikap dan tindakan yang diinginkan dapat terungkap di kelompok. Dari beberapa pengertian tentang kelompok dapat memberikan pencegahan terhadap timbulnya masalah pada siswa dalam mengembangkan potensinya, sehingga dapat membantu siswa untuk mencapai perkembangan yang optimal. 


\section{METODOLOGI PENELITIAN}

Objek penelitian ini SMK Negeri 1 Pasir Penyu adalah 36 orang siswa. Subjek penelitian meliputi hasil observasi, hasil analisis dokumen dan hasil penilaian praktek. Metode yang digunakan bersifat kuantitatif dimana penelitian yang bersifat sistematis, menggunakan modelmodel yang bersifat matematis. Teori-teori yang digunakan serta hipotesa yang diajukan juga biasanya

\section{HASIL PENELITIAN DAN PEMBAHASAN}

Hasil observasi menunjukkan adanya perubahan kepercayaan diri dalam komunikasi lisan siswa berkaitan dengan fenomena alam Menghubungkan antara pengaruh metode belajar yang digunakan dengan hasil belajar yang diraih. Jika hasilnya belajar tidak baik, maka ada metode belajar yang perlu dievaluasi. Begitu juga sebaliknya, jika hasil belajar baik, maka metode belajar perlu ditingkatkan agar hasil lebih baik. Hal ini tertuang dari data-data yang terdapat pada siklus I dan siklus II

sebelum tindakan dan sesudah tindakan. Dari hasil observasi sebelum dan sesudah tindakan dapat dibuat rekap sebagai berikut;

Tabel 1. Rekapitulasi Hasil Observasi Sebelum dan sesudah tindakan

\begin{tabular}{|c|c|c|c|c|c|c|}
\hline \multirow{2}{*}{\multicolumn{2}{|c|}{ No Keterangan }} & \multicolumn{5}{|c|}{ Kategori Keberhasilan } \\
\hline & & $\begin{array}{l}\text { Sangat } \\
\text { Rendah }\end{array}$ & Rendah & Sedang & Tingg & $\begin{array}{l}\text { Sanga } \\
\text { Tinggi }\end{array}$ \\
\hline & \begin{tabular}{|l|} 
Sebelum \\
tindakan
\end{tabular} & - & 2,8 & - & - & - \\
\hline 2 & \begin{tabular}{|l} 
Setelah \\
tindakan I
\end{tabular} & - & - & 3,8 & - & - \\
\hline & $\begin{array}{l}\text { Setelah } \\
\text { tindakan II }\end{array}$ & - & - & - & 4,1 & - \\
\hline
\end{tabular}

Sebelum: Data observasi yang diolah

Berdasarkan tabel 1 diatas dapat dilihat bahwa ada perubahan kepercayaan diri dalam komunikasi lisan siswa Kelas XII ATP 1 sebelum dan sesudah tindakan. Sebelum tindakan, kepercayaan diri dalam komunikasi lisan siswa Kelas XII ATP 1 tergolong rendah dengan skor rata-rata motivasi belajar siswa 2,8 setelah tindakan pada siklus I kepercayaan diri dalam komunikasi lisan siswa Kelas XII ATP 1 meningkat dari rendah menjadi tinggi. Hal ini ditunjukkan oleh skor rata-rata Hal ini nampak pada tabel berikut: tindakan I sebesar 3,8, kemudian setelah diberikan tindakan pada siklus II dapat dilihat ada peningkatan kepercayaan diri dalam komunikasi lisan siswa dari pada tindakan I yang mana skor rata-rata motivasi belajar siswa Kelas XI setelah tindakan II menjadi 4,1. Tinggi rndahnya kepercayaan diri dalam komunikasi lisan siswa kelas XII ATP 1 dpaat dilihat dari persentasi baik secara individual maupun secara klasikal.

Tabel 2. Hasil Belajar Siswa Sebelum Dan sesudah Tindakan I dan II

\begin{tabular}{|c|c|c|c|c|c|c|c|c|c|c|c|}
\hline \multirow{2}{*}{$\mathrm{No}$} & \multirow{2}{*}{ Ket } & \multicolumn{10}{|c|}{ Kategori Keberhasialan } \\
\hline & & SR & $\%$ & $\mathrm{R}$ & $\%$ & $\mathrm{~S}$ & $\%$ & $\mathrm{~T}$ & $\%$ & ST & $\%$ \\
\hline 1 & $\begin{array}{l}\text { Sebelum } \\
\text { Tindakan }\end{array}$ & 6 & 16,7 & 10 & 27.8 & 10 & 27.8 & 11 & 30.6 & - & - \\
\hline 2 & $\begin{array}{l}\text { Setelah } \\
\text { Tindakan I }\end{array}$ & - & - & 5 & 13.9 & 12 & 33.3 & 15 & 41.7 & 13 & 36.1 \\
\hline 3 & $\begin{array}{l}\text { Setelah } \\
\text { Tindakan II }\end{array}$ & - & - & - & - & 10 & 27.8 & 14 & 38.9 & 15 & 41.7 \\
\hline
\end{tabular}


Berdasarkan tabel diatas, nampak bahwa sebelum tindakan 6 siswa $(16,7 \%)$ meperoleh hasil yang sangat rendah, dan 10 siswa $(27,8 \%)$ memperoleh hasil rendah, 10 siswa $(27,8 \%)$ memperoleh hasil sedang daan 11 siswa (30.6) memperoleh hasil tinggi. Setelah diadakan tindakan I terlihat 5 orang siswa $(13,9 \%)$ memperoleh hasil yang rendah dan 12 siswa (33.3\%) memperoleh hasil yang sedang, 15 siswa (41.7\%) memperoleh hasil yang tinggi dan 13 siswa $(36,1 \%)$ memperoleh hasil yang tinggi. Kemudian setelah dilakukan tindakan ke II nampak 10 siswa $(27,8 \%)$ memperoleh hasil yang sedang, 14 siswa 38.9\%) memperoleh hasil yang tinggi $15(41,7 \%)$ memperoleh hasil yang sangat tinggi.

Skor rata-rata kepercayaan diri dalam komunikasi lisan siswa Kelas XII ATP 1 sebelum adanya tindakan adalah 2,8 ini menunjukkan bahwa kepercayaan diri dalam komunikasi lisan siswa Kelas XII ATP 1 berada pada tingkat rendah, hal ini disebabkan karena bimbingan dilakukan kepada siswa kurang menarik. Hanya menggunakan ceramah tanpa mengunakan media. sehingga membuat siswa bosan.

Dari hasil observasi pada situs I, sebanyak 36 siswa memiliki rasa kepercayaan diri dalam komunikasi lisan yang tinggi. Hal ini karena dalam bimbingan menggunakan permainan game role play. Metode ini dapat menarik, memotivasi siswa terhadap bimbingan yang dilakukan, dengan skor ratarata 3.8 .

Selanjutnya Hasil observasi pada siklus II bimbingan menggunakan permainan game role play dengan Topik permainan siswa untuk menyebutkan, menjelaskan dan menginterpretasikan cita-citaku suatu materi yang ringan, sehingga siswa mudah mengkomunikannya secara lisan. Karena materi dan metode dalam bentuk game role play menyenangkan siswa, sehingga siswa dapat bekomunikasi lisan dengan lancar tanpa ada rasa malu, takut, tertekan dan tidak rendah diri. Siswa merasa tertantang untuk menjadikan kelompoknya menjadi yang lebih baik dari kelompok lainnya, sehingga ada rasa tanggung jawab dan kerjasama dalam tim, .

Siswa mengeluarkan segenap pengetahuan dan perhatiannya tercurah pada nama baik kelompok. Terlihat siswa sangat antusias dalam memberikan jawaban. Metode ini dapat menarik, memotivasi siswa terhadap bimbingan yang dilakukan, sehingga kepercayaan diri dalam komunikasi lisan siswa tinggi dengan skor rata-rata 4.1.
Dengan demikian maka dengan diberikan bimbingan secara kelompok dapat meningkatkan kepercayaan diri dalam berkomunikasi lisan bagi siswa kelas XII ATP 1 SMKN 1Pasir Penyu.

\section{SIMPULAN}

Berdasarkan hasil penelitian ini analisis data yang dilakukan telah dilakukan dapat disimpulkan dengan penerapan bimbingan kelompok dapat meningkatkan kepercayaan diri salam berkomunikasi lisan siswa kelas XII ATP 1 SMK Negeri 1 Pasir Penyu. Terdapat beberapa peningkatan rasa kepercayaan diri dalam berkomunikasi lisan siswa dari sebelum diberkan tindakan dn setelah memperoleh tindakan pada 2 siklus. Maka dapat disimpulkan bahwa kepercayaan diri dalam komunikasi lisan siswa kelas XII ATP 1 melalui layanan bimbingan kelompok adalah sebagai berikut:

1. Skor rata-rata kepercayaan diri dalam komunikasi lisan siswa Kelas XII ATP 1 sebelum adanya tindakan adalah 2,8 ini menunjukkan bahwa kepercayaan diri dalam komunikasi lisan siswa Kelas XII ATP 1 berada pada tingkat rendah, hal ini disebabkan karena bimbingan dilakukan kepada siswa kurang menarik. Hanya menggunakan ceramah tanpa mengunakan media. sehingga membuat siswa bosan.

2. Dari hasil observasi pada situs I, sebanyak 36 siswa memiliki rasa kepercayaan diri dalam komunikasi lisan yang tinggi. Hal ini karena dalam bimbingan menggunakan permainan game role play. Metode ini dapat menarik, memotivasi siswa terhadap bimbingan yang dilakukan, dengan skor rata-rata 3.8.

3. Selanjutnya Hasil observasi pada siklus II bimbingan menggunakan permainan game role play dengan Topik permainan siswa untuk menyebutkan, menjelaskan dan menginterpretasikan cita-citaku suatu materi yang ringan, sehingga siswa mudah mengkomunikannya secara lisan. Karena materi dan metode dalam bentuk game role play menyenangkan siswa, sehingga siswa dapat bekomunikasi lisan dengan lancar tanpa ada rasa malu, takut, tertekan dan tidak rendah diri. Siswa merasa tertantang untuk menjadikan kelompoknya menjadi yang lebih baik dari kelompok lainnya, sehingga ada rasa tanggung jawab dan kerjasama dalam tim, Siswa mengeluarkan segenap pengetahuan dan perhatiannya tercurah pada nama baik 
kelompok. Terlihat siswa sangat antusias dalam memberikan jawaban. Metode ini dapat menarik, memotivasi siswa terhadap bimbingan yang dilakukan, sehingga kepercayaan diri dalam komunikasi lisan siswa tinggi dengan skor rata-rata 4.1 .

4. Dengan demikian maka dengan diberikan bimbingan secara kelompok dapat meningkatkan kepercayaan diri dalam berkomunikasi lisan bagi siswa kelas XII ATP 1 SMKN 1 Pasir Penyu.

\section{DAFTAR PUSTAKA}

Agus Hardjana. (2003). Komunikasi Intrapersonal \& Interpersonal.Yogyakarta: Kanisius

Ahmadi, Abu dan Jok tri Prasetya. 1997. Strategi Belajar Mengajar,Bandung : CV Pustaka Setia.

Angelis, Barbara D. 2005. Percaya Diri. Jakarta: Gramedia Pustaka Utama

Arikunto, Suharsimi. 2002. Prosedur Penelitian. Jakarta: Rineka Cipta

Arsyad, Azhar. 2003. Media Pembelajaran. Jakarta: RajaGrafindo Persada

Corey, G. 1984. Theory And Practice of Group Counseling. California, Monterey: Books/Cole Publishing Company

Dimyati dan Mudjiono. 1990. Belajar dan Pembelajaran.Jakarta: Rineka Cipta.

Djamarah, S.B dan Aswan Zain.1996.Strategi Belajar Mengajar. Jakarta: Rineka Cipta

Ena, Ouda Teda. 2001. Membuat Media Pembelajaran Interaktif dengan Piranti Lunak Presentasi. Yogyakarta: Universitas Sanata Dharma Yogyakarta

Gazda, GM.1984. Group Counseling Developmental Approach. Boston: Allyn and Bacon,Inc

Gendrungan. 2004. Psikologi Sosial. Bandung: Refika Aditama

Hadi, Sutrisno. 2002. Metodelogi Research jilid I. Yogyakarta: Penerbit Andi

Hafied Cangara. (2011). Pengantar Ilmu Komunikasi. Jakarta: PT Raja Grafindo

Handoko, Martin 2003. Motivasi Daya Penggerak Tingkah Laku. Jakarta: Kanisius

Hakim, Thursan. 2005. Mengatasi Rasa Tidak Percaya Diri. Jakarta: Puspa Swara
Haryanto.1997 Perencanaan Pembelajaran, Jakarta: Rineka Cipta.

Jacinta F. Rini. (2002). Memupuk Rasa Percaya Diri. Tersedia: http://www.epsikologi.com/dewasa/161--2.htm. Diakses pada tanggal 10 Juli 2019

Lasitosari, Dwi. 2007. Keefektifan Layanan Bimbingan Kelompok Untuk Meningkatkan Percaya Diri Siswa yang Tidak Naik Kelas (Penelitian Eksperimen pada siswa kelas X dan XI SMA N 7 Semarang Tahun Ajaran 2006/2007). Skripsi Jurusan Bimbingan Konseling. FIP UNNES

Lidenfield, Gael. Alih Bahasa Adiati Kamil. 1997. Mendidik Agar Anak Percaya Diri. Jepara. Silas Press

Mastuti, Indari. 2008. 50 Kiat Percaya Diri. Jakarta: Hi-Fest Publishing

Mugiarso, Heru, dkk. 2006. Bimbingan dan Konseling. Semarang: UNNES Press

Slameto.1995 Belajar dan Faktor-Faktor Yang Mempengaruhinya. Jakarta: Rineka Cipta

Sudirman, dkk. 1991.Ilmu Pendidikan. Bandung: Remaja RoSMKakarya.

Sudjana, Nana.1990. Penilaian Hasil Mengajar. Bandung: Remaja RoSM Kakarya

Suharto. 1996. Pendidikan dan Tehnik Dalam Proses Belajar Mengajar. Bandung Transito

Thursan Hakim. (2002). Mengatasi Rasa tidak Percaya Diri. Jakarta: Puspa Swara.

Tim Pelatih Proyek PGSM. 1999. Pendidikan Tindakan Kelas. Jakarta: DirjenPendidikan Tinggi 